\title{
PERSISTENCE OF ARCOBACTER BUTZLERI CCUG 30484 ON PLASTIC, STAINLESS STEEL AND GLASS SURFACES
}

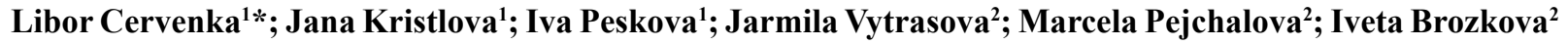 \\ ${ }^{1}$ Department of Analytical Chemistry, Faculty of Chemical Technology, University of Pardubice, Pardubice, Czech Republic; \\ ${ }^{2}$ Department of Biological and Biochemical Sciences, Faculty of Chemical Technology, University of Pardubice, Pardubice, \\ Czech Republic
}

Submitted: May 02, 2007; Returned to authors for corrections: November 15, 2007; Approved: July 06, 2008.

\begin{abstract}
The persistence of A. butzleri CCUG 30484 on various surfaces under $32 \%$ and $64 \%$ relative humidity suspended in physiological saline or nutrient broth to simulate relatively clean or soiled conditions was studied using various isolation techniques. Our study revealed that $A$. butzleri CCUG 30484 cells were able to survive for a considerable period of time, even after the droplet of suspending medium has been visibly dried. An extended survival on polypropylene coupons at both humidity levels was observed, particularly at soiled conditions.
\end{abstract}

Key-words: Arcobacter butzleri, surfaces, persistence.

The genus Arcobacter was proposed to describe the organism previously known as ,aerotolerant campylobacter” (12). Both arcobacters and campylobacters are characterized as fastidious, Gram-negative, non-spore-forming, motile, curveshaped organisms encompassed in the family Campylobacteraceae. Arcobacter butzleri is the most commonly reported human pathogen of the genus Arcobacter. A. butzleri have been isolated from patients with severe diarrhoea (9) and from blood (15). Recently, A. butzleri has been recognized as the fourth most common Campylobacter-like organism isolated from stool specimens during the 8-year study period (13).

The importance of contaminated surfaces in relation to potential transmission of pathogens to food is apparent in food processing, catering and domestic environments. Several studies have indicated that various bacteria survive on sponges, kitchen utensils and kitchen surfaces for considerable periods of time $(3,8,10)$. Campylobacters, a closely related genus to Arcobacter spp., have the reputation to be extremely sensitive to the extraintestinal environment. They are highly susceptible to desiccation and do not survive well on dry surfaces $(3,4,6,14)$. Despite of the phylogenetic similarities observed between Arcobacter and Campylobacter, A. butzleri seemed to be more resistant to desiccation than the classical enteropthogenic Campylobacter species (11).

In the present study, the persistence of $A$. butzleri (strain CCUG 30484) was determined on some typical food contact surfaces (glass, plastic and stainless steel coupons) stored at lower and higher relative humidity ( $32 \%$ and $64 \% \mathrm{RH})$ and at optimal temperature.

A culture of A. butzleri CCUG 30484 (obtained from Culture Collection, University of Göteborg, Sweden) was used in this study. The freshly grown bacteria on Tryptic soy agar plate (Merck, Darmstadt, Germany) in aerobic condition at $30^{\circ} \mathrm{C}$ for $48 \mathrm{~h}$ were harvested and suspended in $5 \mathrm{ml}$ of physiological saline (PS) or Arcobacter basal medium (ABM, Oxoid, Hampshire, UK) to simulate relatively clean or soiled conditions, respectively. The entire experiment was conducted aerobically at optimal temperature of $30^{\circ} \mathrm{C}$.

Samples (approximately $1.5 \times 1.5 \mathrm{~cm}$ coupons) of stainless steel (SS), polypropylene (PP) and glass (GL) were thoroughly cleaned with antibacterial detergent $\left(1: 9 \mathrm{vol} / \mathrm{vol}, \mathrm{Krezosan}^{\circledR}\right.$, Tatrachema, Trnava, Slovakia) followed by rinsing in distilled water and $70 \%$ ethanol. The stainless steel and glass coupons were sterilized for 2 hours at $160^{\circ} \mathrm{C}$, and the polypropylene

*Corresponding Author. Mailing address: Department of Analytical Chemistry, Faculty of Chemical Technology, University of Pardubice, Pardubice, Czech Republic. Tel.: +420 466037 718, fax +420 466037 068. E-mail: libor.cervenka@upce.cz 
coupons were autoclaved for $15 \mathrm{~min}$ at $121^{\circ} \mathrm{C}$ before inoculation with the bacterial suspension.

A 20- $\mu$ l aliquot of the suspension $\left(2 \times 10^{6} \mathrm{CFU}\right)$ was placed in the centre of each coupon to form one droplet, and the coupons were carefully placed in desiccators above the salt slurries of $\mathrm{MgCl}_{2}\left(32 \% \mathrm{RH}\right.$ at $\left.30^{\circ} \mathrm{C}\right)$ and $\mathrm{CoCl}_{2}\left(64 \% \mathrm{RH}\right.$ at $\left.30^{\circ} \mathrm{C}\right)$. Subsequently, the desiccators were held aerobically in a dark room at $30^{\circ} \mathrm{C}$. A set of control time zero coupons $\left(\mathrm{t}_{0}\right)$ were inoculated and immediately processed, as described below, without placement in desiccators, to verify initial concentrations. The relative humidity values of 32 and $64 \%$ were chosen for the purpose of the current study as representative of the lower (i.e. $<50 \% \mathrm{RH})$ and the higher range $(>50 \% \mathrm{RH})$ relative humidities, respectively. In addition, $64 \% \mathrm{RH}$ is representative of the most common relative humidity level found to occur inside buildings.

The coupons were removed from the humidity chamber at the appropriate sampling time and were transferred to $20 \mathrm{ml}$ of $\mathrm{ABM}$ broth and sonicated at $38 \mathrm{kHz}$ for 5 minutes to liberate the attached cells. Subsequently, $100-\mu 1$ of sample was streaked on the ABM agar plate and the bacterial count $\left(\log _{10} \mathrm{CFU}\right.$ per coupon) was determined after aerobic cultivation at $30^{\circ} \mathrm{C}$ for 48 $\mathrm{h}$. Ten-fold dilutions in ABM broth were done if necessary. When no colony forming has been detected, freshly inoculated coupons were removed from the humidity environment at the sampling times and deposited on the surface of ABM agar plate for $5 \mathrm{~min}$. After being aseptically removed, the plates were incubated at $30^{\circ} \mathrm{C}$ for $48 \mathrm{~h}$ in aerobic condition and the viable cells were observed. This procedure will be further discussed as a "coupon-printing method". When the coupon-printing method failed to detect viable cells of $A$. butzleri, an enrichment procedure was performed at further sampling times. The freshly inoculated coupons were removed from the humidity chambers and transferred to $20 \mathrm{ml}$ of ABM or $20 \mathrm{ml}$ of Johnson-Murano basal medium (JMBM, antibiotics were not added) (7) at the sampling time. The enrichment media were incubated at $30^{\circ} \mathrm{C}$ for $72 \mathrm{~h}$ and $168 \mathrm{~h}$ after sonication for $5 \mathrm{~min}$. Therefore $100-\mu \mathrm{l}$ aliquot of enriched sample was plated on ABM agar plate and incubated at $30^{\circ} \mathrm{C}$ for $48 \mathrm{~h}$. The ABM medium represents nonspecific enrichment medium whereas JMBM is selective medium for isolation of arcobacters. Two coupons per each material, cell suspension and humidity environment were used at each sampling time and the experiment was done in triplicate. For bacterial count determined, one- or two-way analysis of variances (ANOVA) at a level of significance $\mathrm{P}<0.05$ was used for statistical treatment (QC. Expert 2.7, Trilobite Ltd., Czech Republic).

The effect of various surfaces and humidity levels on the survival of $A$. butzleri in relatively clean condition is introduced in Table 1. No bacterial count was detected after 1.5 and $2.0 \mathrm{~h}$ of exposure to $32 \%$ and $64 \% \mathrm{RH}$, respectively. The number of cells has significantly decreased in polypropylene surfaces after $1 \mathrm{~h}$ of exposure to $32 \% \mathrm{RH}(\mathrm{p}<0.05)$, and after $1.5 \mathrm{~h}$ when exposed to $64 \% \mathrm{RH}(\mathrm{p}<0.05)$ in comparison with initial bacterial counts. An extended survival on PP coupons at both humidity levels

Table 1. Persistence and recovery of Arcobacter butzleri CCUG 30484 suspended in physiological saline on work surfaces at $32 \%$ and $64 \%$ relative humidity at $30^{\circ} \mathrm{C}$.

\begin{tabular}{|c|c|c|c|c|c|c|}
\hline Sampling time $(\mathrm{h})$ & \multicolumn{2}{|c|}{ Polypropylene } & \multicolumn{2}{|c|}{ Stainless steel } & \multicolumn{2}{|c|}{ Glass } \\
\hline 0 & ${ }^{\mathrm{x}} 6.12 \pm 0.22_{\mathrm{a}}$ & $\times 5.95 \pm 0.34 \mathrm{a}$ & ${ }^{\mathrm{x}} 6.02 \pm 0.27 \mathrm{a}$ & $\mathrm{x} 6.01 \pm 0.45_{\mathrm{a}}$ & $\mathrm{x} 6.05 \pm 0.50_{\mathrm{a}}$ & $\times 5.96 \pm 0.16$ \\
\hline 1.0 & $\times 5.36 \pm 0.36_{b}$ & $\times 5.63 \pm 0.35_{\mathrm{ab}}$ & $\times 5.21 \pm 0.43_{\mathrm{a}}$ & $\times 5.60 \pm 0.46_{a}$ & $\times 5.48 \pm 0.41_{\mathrm{a}}$ & $\times 5.8 \pm 0.19$ \\
\hline 1.5 & $+^{*}$ & $\times 5.10 \pm 0.21_{b}$ & - & $\times 5.02 \pm 0.26 \mathrm{a}$ & - & $\times 5.43 \pm 0.53$ \\
\hline 3.0 & $+\#, \pm$ & $+\#$ & $-^{ \pm}$ & $+^{\#}$ & - \pm & $+^{\#}$ \\
\hline 3.5 & $-^{ \pm}$ & $+\#$ & $-^{ \pm}$ & $-^{ \pm}$ & $-^{ \pm}$ & $-^{ \pm}$ \\
\hline 5.5 & - \pm & $+\#, \pm$ & - \pm & $-^{ \pm}$ & - \pm & - \pm \\
\hline 6.5 & $-^{ \pm}$ & $-^{ \pm}$ & $-^{ \pm}$ & $-^{ \pm}$ & $-^{ \pm}$ & $-^{ \pm}$ \\
\hline
\end{tabular}

Bacterial count is expressed as $\log _{10} \mathrm{CFU}$ per coupon (mean \pm standard deviation);

+ - growth/no growth on $\mathrm{ABM}$ agar plate after incubation at $30^{\circ} \mathrm{C}$ for $48 \mathrm{~h}$ in aerobic condition;

* the cells were detected using a coupon-printing method;

\# the cells were recovered using an enrichment procedure (Arcobacter basal medium, Oxoid, Hampshire, UK);

${ }^{ \pm}$indicates completely dried inoculum (20 $\mu$ l droplet);

${ }^{w-y}$ Means with different superscript letters within a row are significantly different at $p<0.05$;

a-c Means with different subscript letters within a column are significantly different at $\mathrm{p}<0.05$. 
for more than $0.5 \mathrm{~h}$ compared to those detected by the counting method was observed using the coupon-printing method. However, A. butzleri suspended in physiological saline was successfully recovered from PP coupons even after $3.0 \mathrm{~h}$ of exposure to $32 \% \mathrm{RH}$ using enrichment in ABM. It has to be noted that the inoculum was completely dried at this time. The bacterial cells were also resuscitated from completely dried PP and GL surfaces exposed to $64 \% \mathrm{RH}$.

Regarding $\mathrm{ABM}$ as a suspending medium simulating a relatively soiled environment, no bacterial count was observed after $2 \mathrm{~h}$ of exposure in all the experimental conditions (Table 2). The cell number significantly decreased in PP coupons after 1.5 $\mathrm{h}$ of exposure to both $32 \%$ and $64 \% \mathrm{RH}$ and after $1.5 \mathrm{~h}$ when glass and stainless steel coupons were exposed to $64 \% \mathrm{RH}$. Prolonged survival of $A$. butzleri was observed under $32 \% \mathrm{RH}$ while using the coupon-printing method. The viable cells were detected after 3.0 and $3.5 \mathrm{~h}$ for SS and PP surfaces, respectively and after $2.5 \mathrm{~h}$ for GL. Moreover, A. butzleri was successfully detected after $3.5 \mathrm{~h}$ of exposure to $64 \% \mathrm{RH}$ in all the surfaces examined as well. Once the droplet containing A. butzleri desiccated, the viable cells were only detected using an enrichment procedure (ABM broth) extending the survival to 5.5 and $6.5 \mathrm{~h}$ of exposure to 32 and $64 \% \mathrm{RH}$, respectively. No viable cells were detected in all the surfaces tested using an enrichment procedure after $24 \mathrm{~h}$ of exposure. As expected, the cells were even recovered when the inoculum remained liquid under both relative humidity levels using JMBM within the experiment. The similar results were obtained by Gough and Dodd (5) who found the higher recovery of damaged Salmonella Typhimurium cells in non-selective agar compared with the selective medium for Salmonella species, i.e. xylose-lysine desoxycholate agar.

To our best knowledge, there is a small contribution concerning desiccation tolerance of A. butzleri strains isolated from commercial chicken liver (11). Authors found that arcobacter strains did not resist desiccation in the range from 2 to $36 \mathrm{~h}$. In our study, A. butzleri strain was able to survive from 1.0 to $5.5 \mathrm{~h}$ in condition of low relative humidity $(32 \% \mathrm{RH})$ regardless of surface material or suspending medium used. At $64 \% \mathrm{RH}$, the most common relative humidity level inside buildings, the desiccation tolerance was enhanced up to $6.5 \mathrm{~h}$. It is well known that campylobacters are extremely sensitive to a dry condition being capable of prolonged survival on work surfaces if the drops (blood) remained liquid (6). Regarding $A$. butzleri CCUG 30484, the viable cells were still detected at certain conditions even after the suspending medium had dried.

It was previously published that the type of material and suspending medium play a key role in attachment of bacterial cells and hence induced their persistence and recovery from surfaces. For instance, C. jejuni (various types of strains) better survived in phosphate-buffered saline (nutritionally depleted) than in Tryptic soy broth (nutritionally rich) on hard contact surfaces. This behavior was related to the presence of components in Tryptic soy broth that were toxic to C. jejuni

Table 2. Persistence and recovery of Arcobacter butzleri CCUG 30484 suspended in Arcobacter basal medium on work surfaces at $32 \%$ and $64 \%$ relative humidity at $30^{\circ} \mathrm{C}$.

\begin{tabular}{|c|c|c|c|c|c|c|}
\hline \multirow{2}{*}{ Sampling time (h) } & \multicolumn{2}{|c|}{ Polypropylene } & \multicolumn{2}{|c|}{ Stainless steel } & \multicolumn{2}{|c|}{ Glass } \\
\hline & $32 \% \mathrm{RH}$ & $64 \% \mathrm{RH}$ & $32 \% \mathrm{RH}$ & $64 \% \mathrm{RH}$ & $32 \% \mathrm{RH}$ & $64 \% \mathrm{RH}$ \\
\hline 0 & ${ }^{\times} 6.45 \pm 0.40_{a}$ & ${ }^{\times} 6.60 \pm 0.35_{a}$ & $\mathrm{x} 6.52 \pm 0.32 \mathrm{a}$ & ${ }^{\mathrm{x}} 6.62 \pm 0.31_{\mathrm{a}}$ & $\times 6.55 \pm 0.25 \mathrm{a}$ & $\times 6.60 \pm 0.50_{a}$ \\
\hline 0.5 & $\times 6.02 \pm 0.62_{\mathrm{ab}}$ & ${ }^{\times} 6.25 \pm 0.16_{\mathrm{ab}}$ & $\times 6.03 \pm 0.54$ & ${ }^{\times} 6.25 \pm 0.32_{\mathrm{ab}}$ & $\times 6.01 \pm 0.67 \mathrm{a}$ & ${ }^{\times} 6.28 \pm 0.09_{a}$ \\
\hline 1.0 & $\times 5.80 \pm 0.25_{\mathrm{ab}}$ & ${ }^{\times} 6.12 \pm 0.15_{\mathrm{ab}}$ & $\times 5.60 \pm 0.49 \mathrm{a}$ & $\times 5.75 \pm 0.40_{\mathrm{ab}}$ & $\times 5.60 \pm 0.48_{\mathrm{a}}$ & $\times 5.87 \pm 0.15_{\mathrm{ab}}$ \\
\hline 1.5 & w $3.30 \pm 0.34_{c}$ & $\times 5.75 \pm 0.25 \mathrm{~b}$ & $+^{*}$ & $\mathrm{y}_{4} 4.75 \pm 0.28_{\mathrm{c}}$ & $+^{*}$ & $\times 5.45 \pm 0.23_{\mathrm{b}}$ \\
\hline 2.0 & $+^{*}$ & $+^{*}$ & $+^{*}$ & $+^{*}$ & $+^{*}$ & $+{ }^{*}$ \\
\hline 2.5 & $+^{*}$ & $+^{*}$ & $+^{*}$ & $+{ }^{*}$ & $+{ }^{*}$ & $t^{*}$ \\
\hline 3.0 & $+^{*}$ & $+^{*}$ & $+{ }^{*}$ & $+*$ & $+\#$ & $+{ }^{*}$ \\
\hline 3.5 & $+^{*}$ & $+^{*}$ & $+\#, \pm$ & $+*$ & $+\#, \pm$ & $+^{*}$ \\
\hline 5.5 & $+^{\#, \pm}$ & $+\#$ & $+\#, \pm$ & $+\#, \pm$ & $+\#, \pm$ & $+\#, \pm$ \\
\hline 6.5 & $\pm^{ \pm}$ & $+\#, \pm$ & $--^{ \pm}$ & $+\#, \pm$ & $-^{ \pm}$ & $+^{\#, \pm}$ \\
\hline
\end{tabular}

Bacterial count is expressed as $\log _{10} \mathrm{CFU}$ per coupon (mean \pm standard deviation);

+/- growth/no growth on ABM agar plate after incubation at $30^{\circ} \mathrm{C}$ for $48 \mathrm{~h}$ in aerobic condition;

* the cells were detected using a coupon-printing method;

\# the cells were recovered using an enrichment procedure (Arcobacter basal medium, Oxoid, Hampshire, UK);

${ }^{ \pm}$indicates completely dried inoculum $(20 \mu 1$ droplet $)$;

${ }^{w-y}$ Means with different superscript letters within a row are significantly different at $p<0.05$;

a-c Means with different subscript letters within a column are significantly different at $\mathrm{p}<0.05$. 
when concentrated by the evaporation of water (3). However, our results showed that $A$. butzleri CCUG 30484 better persisted on hard surfaces when suspended in nutritionally rich medium compared with physiological saline (a lack of nutrient).

More recent works have been focused on determining the survival or persistence of $C$. jejuni in relation to the type of surfaces $(2,3,14)$. In our study, A. butzleri was generally found to be more persistent on PP surfaces as was determined by the coupon-printing method regardless of the suspending medium. The prolonged persistence of A. butzleri on PP in comparison with SS and GL could be due to different surface characteristics of material used. The more hydrophobic surface may result in a small droplet diameter (a higher droplet height), a slower drying rate and hence a longer lag time, since the bacterial cells remain viable in a hydrated environment for a longer period (3). Theoretically, A. butzleri cells could attach in higher numbers to surfaces with low surface free energy (polyethylene) compared to those of higher surface free energy (stainless steel, copper) (1).

In a conclusion, our study revealed that $A$. butzleri CCUG 30484 cells were able to survive for a considerable period of time, even after the droplet of suspending medium has been visibly dried. Although one single strain was used in the current study (originally isolated from swine feces), the results may indicate the potential for cross-contamination in kitchens as a serious problem, especially when some food residues remain on the surface. In addition, the use of medium designed for the isolation of arcobacters from foods may lead to false negative results. Nevertheless, more A. butzleri strains from various sources need to be involved in further studies in order to generalize these claims.

\section{ACKNOWLEDGEMENT}

This work was supported in part by a grant from the Ministry of Education, Youth and Sports of the Czech Republic (no. 0021627502), and from the Czech Science Foundation (no. 203/ 08/1536).

\section{RESUMO}

\section{Persistência de Arcobacter butzleri CCUG 30404 em superfícies de plástico, aço inox e vidro}

Estudou-se a persistência de Arcobacter butzleri CCUG 30404 em várias superfícies de contato com alimentos a 32\% e $64 \%$ de umidade relativa, suspenso em salina fisiológica e caldo nutriente para simular condições limpas e sujas. Nosso estudo indicou que $A$. butzleri CCUG 30404 foi capaz de sobreviver por longo tempo, mesmo após a secagem da gota. Observou-se que a sobrevivência for mais prolongada nos cupons de polipropileno, especialmente em condições sujas.

Palavras-chave: Arcobacter butzleri, superfícies, persistência.

\section{REFERENCES}

1. Assanta, M.A.; Roy, D.; Lemay, M.J.; Montpetit, D. (2002). Attachment of Arcobacter butzleri, a new waterborne pathogen, to water distribution pipe surfaces. J. Food Prot., 65, 1240-1247.

2. Cools, I.; Uyttendaele, M.; Cerpentier, J.; D’Haese, E.; Nelis, H.J.; Debevere, J. (2005). Persistence of Campylobacter jejuni on surfaces in a processing environment and on cutting boards. Lett. Appl. Microbiol., 40, 418-423.

3. De Cesare, A.; Sheldon, B.W.; Smith, K.S.; Jaykus, L.A. (2003). Survival and persistence of Campylobacter and Salmonella species under various organic loads on food contact surfaces. J. Food Prot., $66,1587-1594$.

4. Fernández, H.; Vergara, M.; Tapia, F. (1985). Dessication resistence in thermotolerant Campylobacter species. Infection, 13, 197.

5. Gough, N.L.; Dodd, C.E.R. (1998). The survival and disinfection of Salmonella typhimurium on chopping board surfaces of wood and plastic. Food Control, 9, 363-368.

6. Humphrey, T.; Mason, M.; Martin, K. (1995). The isolation of Campylobacter jejuni from contaminated surfaces and its survival in dilluents. Int. J. Food Microbiol., 26, 295-303.

7. Johnson, L.G.; Murano, E.A. (1999). Comparison of three protocols for the isolation of Arcobacter from poultry. J. Food Prot., 62, 610-614.

8. Kusumaningrum, H.D.; Riboldi, G.; Hazeleger, W.C.; Neumet, R.R. (2003). Survival of foodborne pathogens on stainless steel surfaces and cross-contamination to foods. Int. J. Food Microbiol., 85, 227236.

9. Lerner, J.; Brumberger, V.; Preac-Mursic, V. (1994). Sever diarrhoea associated with Arcobacter butzleri. Eur. J. Clin. Microbiol., 13, 660-662.

10. Mattick, K.; Durham, K.; Domingue, G.; Jorgensen, F.; Sen, M.; Schaffner, D.W.; Humphrey, T. (2003). The survival of foodborne pathogens during domestic washing-up and subsequent transfer onto washing-up sponges, kitchen surfaces and food. Int. J. Food Microbiol., $85,213-226$.

11. Otth, L.; Wilson, M.; Fernández, H. (2001). Dessication resistance in Arcobacter butzleri. Braz. J. Microbiol., 32, 311-312.

12. Vandamme, P.; De Lay, J. (1991). Proposal for a new family Campylobacteraceae. Int. J. Syst. Bacteriol., 41, 451-455.

13. Vandenberg, O.; Dediste, A.; Houf, K.; Ibekwem, S.; Souayah, H.; Cadranel, S.; Douat, N.; Zissis, G.; Butzler, J.P.; Vandamme, P. (2004). Arcobacter species in humans. Emerg. Infect. Dis., 10, 1863-1867.

14. Wanyenya, I.; Muyanja, C.; Nasinyama, G.W. (2004). Kitchen practices used in handling broiler chickens and survival of Campylobacter spp. on cutting surfaces in Kampala, Uganda. J. Food Prot., 67, 1957-1960

15. Yan, J.J.; Ko, W.C.; Juany, A.H.; Chen, H.M.; Jin, Y.T.; Wu, J.J. (2000). Arcobacter butzleri bacteremia in a patient with liver cirrhosis. J. Formos. Med. Assoc., 99, 166-169. 